\title{
CASE C-138/13, NAIME DOGAN v. BUNDESREPUBLIK DEUTSCHLAND
}

(Judgment of 10 July 2014, not yet reported)

\section{Mattia FILIPPIN* Nanette NEUWAHL ${ }^{* *}$}

\section{Epilogue}

Naime Dogan is the wife of a Turkish national economically active in Germany, who was denied an entry visa by the German authorities on the ground, that her German language skills were insufficient. She had passed an oral test but because she was illiterate, she had guessed the answers to a written test and had been unlucky as to the results. On this ground she had been denied a visa for spousal reunion. The refusal of the visa meant that she could only visit her husband on short term tourist visas and she was not able to enjoy a right to reunion with her spouse of 13 years in Germany. She contested the refusal. This then gave rise to two issues of EU law referred to the Court of Justice of the European Union (hereinafter 'the Court of Justice') for a preliminary ruling, namely, whether there was a violation of Article 41(1) of the 1970 Additional Protocol to the 1963 Association Agreement between the EU and Turkey (hereinafter 'Ankara Agreement'), and if not, whether there was a breach of Directive 2003/86 on family reunification, which allows Member States to require compliance with 'integration measures'.

With regard to the first issue the Court, to which the matter was referred, held that: "Article 41(1) of the Additional Protocol must be interpreted as meaning that the 'standstill' clause set out in that provision precludes a measure of national law, introduced after the entry into force of that additional protocol in the Member State concerned, which imposes on spouses of Turkish nationals residing in that Member State, who wish to enter the territory of that State for the purposes of family

\footnotetext{
*Academic Assistant, College of Europe, Natolin Campus. e-mail: mattia.filippin@coleurope.eu ** Jean Monnet Professor of EU Law, Université de Montréal and College of Europe, Natolin Campus. e-mail: nanette.neuwahl@umontreal.ca
} 
reunification, the condition that they demonstrate beforehand that they have acquired basic knowledge of the official language of that Member State."

The Court of Justice did not reply to the second issue.

\section{Impact of the judgment}

The immediate comments on the case were euphoric. In particular, Steve Peers, a leading professor on migration law has commented that the Court of Justice has 'transformed family reunion for Turkish citizens ${ }^{1}$ and Rolf Gutmann, a leading practitioner, also mentions a great variety of ways in which the judgment could be used. ${ }^{2}$ Nevertheless, it may well be too early to rejoice. Although the judgment confirms a wide application of the standstill clause of the Additional Protocol (because covering the treatment of family members of the economically active as well as the economically active himself), the immediate impact of the judgment is only a droplet in the ocean. This is so for several reasons: Because Article 41(1) does not give en entitlement to a right of family reunion, it forbids merely a tightening of the conditions, and only if this is done in an arbitrary or discriminatory way, as might have been the case with Mrs. Dogan. Furthermore, even if Germany may have to amend its immigration legislation, the impact of the judgment may not go much further than whatever efforts the German legislator is willing to undertake to comply with the case law. On its narrowest interpretation, the judgment just implies that the blanket refusal of the first entry of spouses of Turkish immigrants who do not pass a language test is illegal.

The truth is therefore that the exact impact of the judgment is hard to predict. Ideally, the German legislation affecting Turkish and other nationals is overhauled, but we are not aware of the intention of the legislator to do that. To argue that this judgment will bring about a seismic change in the situation of many immigrants in Germany is unwarranted. For the immigrants and their families this is of course regretful, because it is not within everyone's possibility to litigate to the highest courts in order to obtain a more favourable application of the law than is currently being provided.

And, what is equally important, EU law as it stands does not eliminate the use of language tests for foreign nationals by any stretch of the imagination. The very

\footnotetext{
${ }^{1}$ Steve Peers, "CJEU Transforms Family Reunion for Turkish Citizens”, 12 July 2014. Internet resource at http://eulawanalysis.blogspot.com/2014/07/the-cjeu-transforms-family-reunion-for.html, last visited on 9 August 2014.

${ }^{2}$ Rolf Gutmann, “Ausweitung des Assoziationsrechts”, paper not yet published but submitted for publication.
} 
existence of those tests is a formidable disincentive for free movement and an impediment to the benefits it brings to any society.

\section{Procedural economy and the Directive on family reunification}

The Court of Justice has not answered the question on the interpretation of Directive 2003/86 on family reunification, considering that an answer to that question was not necessary for the Berlin Administrative Court to take a decision in the case at hand. Procedural economy allows the Court of Justice to decline answering a point of law if the decision can be dealt with on the basis of a conclusive answer to the first question.

By contrast, the Advocate General does deal with the question. ${ }^{3}$ According to his saying, he does so in order to deal with the eventuality that his answer to the first question was not conclusive. The Advocate General appears to be of the view that the German application of the law is in conflict with the directive, largely for the same reasons as those applying in the context of the Ankara Agreement: a national law that leads automatically to a rejection of the request for family reunification and which does not allow for the consideration of special circumstances of specific individuals that plead against the application of the law on convincing grounds is a disproportionate measure hindering the attainment of the objective of the directive, namely: family reunification.

The Advocate General's opinion, by answering the question and by the way in which he does it, reveals several issues concerning the interpretation of this directive:

- The family reunification directive is to be interpreted widely and any derogations to it narrowly.

- Any application of the directive, to be legitimate, needs to take into consideration the particular circumstances of the individuals concerned.

- The national judge needs to supervise the rightful application of the directive and disapply any national provisions that hinder its full effect.

These elements are not new as they would apply to any directive and indeed any measure of EU law. They are not controversial.

What is it, then, that the European Court of Justice 'withholds' from us by declining the answer to the second question?

\footnotetext{
${ }^{3}$ See also Nanette Neuwahl, “ 'No German, No Love'- Language Proficiency as a Condition for Visas of Turkish Spouses under EU Law", 21/2 Marmara Journal of European Studies (2014), 1-36.
} 
It is the answer to the question whether Article 7(2) of the directive may be used as a means for selecting the persons who may benefit from family reunification, or whether it is simply intended to facilitate integration into the Member State. In the view of the Advocate General, the answer to that question is the latter. ${ }^{4}$

The question whether Member States may make the right to family reunification conditional upon language proficiency is a complicated one. One may suggest that there is almost always the possibility for a couple to form or maintain a family in the country of origin, so that it is possible to speak of an infringement of the right to family reunification only if it is impossible or excessively burdensome for one of the two persons in the couple, or for dependant relatives to (travel or) move out of the country. One may especially think of the interest of the children in this connection. In that assumption, it would be almost as if the right to family reunification did not really exist in the Member State concerned in relation to immigrants. It would be permitted to use linguistic skills as a criterion for the selection of immigrants by any State, be it that there may be circumstances which need to be treated as derogations.

If this is the case, then, it is also true to say that the Directive on family reunification has decreased the margin of discretion of the Member States to which it applies. This assumption is hardly disputable given the objective of the directive, namely, to accord a right to family reunification to those persons who are concerned by it, and to harmonize national law as much as possible so as to attain that objective.

While one can accept that the Court of Justice declines to answer some questions out of a desire to exercise procedural economy, one may regret that the Court did not answer the question, because the Directive on family reunification applies to a wider circle of third country nationals than the Ankara Agreement - be it to a narrower circle of Member States. A statement from the Court would have eliminated legal uncertainty. Besides, procedural economy on the European level is not necessarily equivalent to procedural economy on the national level, where, due to the decentralized judicial system, litigation is mainly directed at.

The second question is currently before Court of Justice in another case, $K$ and $A$, but this will take some time to be decided because it was registered only on April 3, 2014. ${ }^{5}$ Also, it cannot be excluded that the matter will be settled out of court and the case withdrawn before the judgment date.

\footnotetext{
${ }^{4}$ Marginal 53 of the Advocate General's Opinion.

${ }^{5}$ Case C-153/14, request for a preliminary ruling by the Netherlands' Raad van State.
} 